\title{
Theology and the building of civilizing democracy in South Africa
}

NGTT DEEL 55, NR 3 \& 4, 2014

Koopman, Nico

Stellenbosch University

\begin{abstract}
This paper discusses the contribution of theology to the building of a civilizing democracy, i.e. a democratic society where a life of justice to all is advanced. A society is only "civilized" where justice to especially the most vulnerable is advanced. Justice rests in dignity and co-exists with equality and equity, as well as with freedom. Theology makes a threefold contribution towards a society of justice. Theology reveals the deeper meaning-giving framework, and forces of social cohesion and moral living without which a liberal democracy cannot flourish. Theology offers richer descriptions of notions like justice, which advance the implementation and fulfilment of these features. Theology makes a contribution towards the mobilization of an activist civil society and citizenship in search of a civilizing society of justice.
\end{abstract}

\section{KEYWORDS}

Dignity, Justice, Equality, Freedom, Civil society, Civilising

TREFWOORDE

Menswaardigheid, Geregtigheid, Gelykheid, Vryheid, Burgerlike samelewing, Siviliserende

\section{KONTAKBESONDERHEDE}

Prof Nico Koopman

Dean of the Faculty of Theology at Stellenbosch University

Privaatsak X1, Matieland, Suid-Afrika, 7602

nkoopman@sun.ac.za 


\section{INTRODUCTION}

In 2014 South Africans celebrate twenty years of democracy. On the $27^{\text {th }}$ of April 1994 millions of South Africans could vote for the first time in an inclusive, participatory, constitutional, and may I add, civilizing, democracy.

The notion of civilizing democracy is used with caution. Notions like civilization, civilizing, civil and civilized are in need of de-contamination. These notions became polluted and even hurtful notions in the context of colonialism and apartheid. They became to be associated with dehumanization and racism, injustice and oppression.

On the continent of Africa these notions came to be associated with the conscious, and current mostly sub-conscious, idea that some ethnic groups are inferior to others, with regard to factors like physical appearance and beauty, intellect and morality, and even the capacity to enter into relationship with God. The so-called superior ethnic groups were viewed as the more civilized ones. Those on the lower end of the hierarchy of ethnic groups, most notably black and Coloured people from Africa, were viewed as the least civilized ones. Racism was a specific form of dehumanization of people. Based on the ideology and picture of racism, social structures were developed that had distributed the necessities, goods and opportunities of society to ethnic groups in terms of their position on this ladder of ethnocentrism and racism. The levels of dignity, justice and freedom that people were allowed to experience were determined by where they were placed on this ladder of racism.

The notion of civilizing democracy is used in this essay with a twofold meaning. It firstly argues the point that a civilizing democracy is one that acknowledges, affirms and advances a life of justice for all, justice that is based in dignity for all, justice that is expressed in equality and freedom for all - for all human beings and for all of creation. Without the materialization of justice to all, especially justice to the most vulnerable, societies cannot claim to be civilized and dignified. Where civilizing democracy is used in this meaning, the notion of civilization and civilized becomes decontaminated and liberating.

The idea of civilizing democracy secondly makes the point that a democracy fulfils this civilizing and dignifying function where there is an activist civil society, which advances the vision of justice for all. It is argued that democracies cannot fulfil this high calling without the active participation of civil society. For democracies to achieve their noble visions, the sustained contribution of an activist civil society, i.e. of both activist institutions of civil society, and have individual citizens or groups of citizens are indispensable. 
The major part of this paper specifically emphasizes the role that theology can play in the quest for a life of justice for all, in the quest for a civilizing society where justice prevails. This paper proposes a threefold contribution of theology to the actualization of justice for all.

Theology firstly has the task to show that democracies cannot flourish without an awareness of the deeper meaning-giving frameworks that gave birth to democracy with its emphasis on values like justice, dignity and freedom for all. Despite their ambivalent track record, faith convictions did contribute to the birth of a democratic ethos. The birth of democracies occurred in the awareness of the presence of meaning-giving frameworks. Democracies presuppose these meaning-giving frameworks, motivations and over-arching purposes of a good life for all.

Theology, secondly, enriches and deepens, widens and strengthens the values that are so central for democratic societies and for our human quests and longings for a life of justice for all. This section constitutes the major part of this essay.

The third contribution of theology is to facilitate the mobilization and guidance of latent energies for justice quests in Christian churches, in other religious bodies, in other institutions of civil society, as well as in individual citizens and groups of citizens.

These three tasks of theology provide the structure for this essay. In a first round the theological wells from which democracies drink since their inception is briefly discussed. In a second section the illuminating role that theology plays with regard to our understanding of justice is discussed. And in a third round the role that theology can play in mobilizing civil society to participate actively in justice quests is investigated.

\section{THEOLOGY AND THE SPIRITUAL WELLS FROM WHICH CIVILIZING DEMOCRACIES DRINK?}

North American theologian, Max Stackhouse, ${ }^{1}$ argues that the task of Public Theology and Theological Ethics is, amongst others, the ethological task, which entails the interpretation and description of the social contexts of life at the deepest moral and spiritual levels. Not only the ethos is discerned, i.e. the web of values and norms, the obligations, virtues, convictions, mores, purposes, expectations and legitimations that form the culture or operating norms of a social entity or

1 M Stackhouse with P Paris (eds.), God and Globalization: Theological ethics and the spheres of life. Vol 1: Religion and the powers of the common life, (New York/London: Continuum, 2000). p 9-18. 
set of social practices, but also the vision of ultimate reality that stands behind the ethos and that legitimates it and that provides it's compelling meaning. Theology identifies, brings to light and discerns the overarching meaning-giving framework within which democratic values are developed and nurtured.

Dutch theologian, Harry Kuitert, ${ }^{2}$ strongly argued that although the church is not the mother (moeder) of the contents of moral convictions, it is the protector (hoeder) and nurturer (voeder) of those moral values through the meaning-giving frameworks, comprehensive visions of the good life, and the theological motivation for good living that it offers.

Oliver O'Donovan ${ }^{3}$ also attributes the development of early liberal thinking and democratic values to a foundation of transcendence, specifically to monotheistic faith and monotheistic traditions and communities in which the conscience of individuals were formed and in which an individual lived with a sense of vocation and the mandate to respond to, answer to, God. Late liberal thinking, however, developed, in the name of a polytheistic approach in pluralistic societies, a selfserving, materialistic, secular approach in which the idea of a monotheistic deity was removed, the idea of an exalted human being was eliminated and the door was opened for an impoverished view of human nature. Liberal societies experience immense problems and struggle to fulfil the democratic vision, because it makes humans feel under-estimated and under-valued. Contemporary late liberal societies do not take the spiritual capacities of its members seriously. Therefore a reaction against its values and aims are unavoidable.

In the United States John Witte ${ }^{4}$ argues over many years that the theologians of the Reformation, especially thinkers of the Reformed tradition, despite their own fallible justice practices, helped to pave the way for modern democratic values like justice, freedom and human rights. And in Germany the notion is well proclaimed that libertarian, secularized states live by prerequisites that it cannot guarantee itself. German constitutional judge, Ernst-Wolfgang Böckenförde, articulated this position. ${ }^{5}$ The Böckenförde-thesis entails that secular democracies need

2 HM Kuitert, Het Schriftberoep in de ethiek, in: HM Kuitert, Anders gezegd. Een versameling van opstellen voor de welwillende lezer, (Kampen: Kok, 1974). p195.

3 O O'Donovan, The ways of judgment, (Grand Rapids: Eerdmans Publishing Co., 2007). p 75-77.

4 J Witte JR, The Reformation of Rights. Law, Religion and Human Rights in Early Modern Calvinism, (Cambridge: Cambridge University Press, 2007).

5 Ernst-Wolfgang Böckenförde, State, Society and Liberty: Studies in Political Theory and Constitutional Law, (New York: N.Y. Berg, 1991). 
interior regulation, i.e. the moral substance of individuals and some form of social homogeneity in order not to disintegrate. In South Africa Allan Boesak ${ }^{6}$ pleads with political and social thinkers and practitioners to acknowledge and discern to a greater extent the indispensable role of religion in breaking down apartheid, and in advancing a society of dignity, justice and freedom.

Charles Mathewes ${ }^{7}$ is so serious about these transcendent roots of modern democracies that he does not even want to talk about public theology, but rather about a theology of public life. He, wrongly I think, view public theology as attempts to merely make democracies work, as attempts to bring some transcendence into the secular, worldview free, public zone. According to him public theology poses the question: what does God have to do with public life. According to him the question that a theology of public life, however, asks is: what does public life have to do with God. A theology of public life, therefore, acknowledges that God is the source and norm of all being and reality. All of life, also political life, rest in God and are to be defined from God's perspective, not the other way around. Theologians, Mathewes continues, should not argue for the legitimacy of religion in public life, but for the legitimacy of public life in religion. As somebody attempting to do public theology, I strongly agree with Mathewes, and I view what he pleads for as an indispensable part of the agenda of public theology.

Mark Mattes ${ }^{8}$ reasons that theology should also expose the wrong mythoi and concomitant doctrines with which the world legitimizes its power and interprets its behaviour.

In bringing to light these religious, transcendent and spiritual underpinnings of democratic visions, values and practices, theologians should not speak in triumphal and arrogant manner. This task should rather be undertaken with humility and in the awareness that the history of the church is contaminated by betrayals of these convictions and values by churches ourselves. The fact that we continuously struggle to reflect the values of justice and togetherness as churches, especially ethnically divided Reformed churches in South Africa, stirs us to more humility. A humble approach also ensures that we do not function with the pretention that we do have final answers to all questions about life and meaning. A Public Theology practiced

6 A Boesak, The tenderness of conscience. African Renaissance and the spirituality of politics, (Stellenbosch: Sun Press, 2005).

7 C Mathewes, A theology of public life (Cambridge: Cambridge University Press, 2007), p 10.

8 MC Mattes, The role of justification in contemporary theology (Grand Rapids: William B. Eerdmans Publishing Company, 2004), p 186. 
in genuine, and not manipulative, humility also shows openness to the lessons to be learnt from circles outside the Christian faith.

This task should also not be done with imperialism. The contributions of other religious traditions and secular traditions should also be discerned, acknowledged and welcomed. The task should be done with openness and hospitality to the other. This hospitality entails that we give space to the other to decide whether they want to accept our gift, and attend to our contribution. This hospitality also entails that we allow the guest to become host, that we also give the other the opportunity to share their gift with us, and that we attend to their gift. This is especially the case in South Africa where various religious and secular persons worked together to break down apartheid and also to lay the foundations for a civilizing democracy. The resistance to an imperialist approach, which is embodied in a humble and hospitable approach, will also prevent this public task of theology to be identified with attempts at proselytizing.

\section{THEOLOGY AND “THICKER” JUSTICE FOR ALL}

Democratic societies hunger for a life of justice for all. Justice is due to all humans because all humans have inalienable dignity. We can therefore say that our dignity has Trinitarian sources. Our dignity is based in the person and work of the electing Father, the creating Father, the providing Father, the caring Father. Our dignity resides in the fact that God takes human beings so seriously that God becomes human in Jesus Christ, the kenotic Christ, the incarnated Christ, the crucified Christ, the resurrected Christ, the ascended Christ, the reigning Christ, the returning Christ. Our dignity is based in the person and work of the Holy Spirit, the indwelling Spirit, the working Spirit, the actualizing, operationalizing, implementing, materializing, embodying, shape-giving, fulfilling Spirit, the transforming Spirit, the renewing Spirit, the perfecting Spirit.

In pluralistic public discourses theology tables these thicker understandings of the roots of our inalienable dignity, and theology does this in humble, hospitable and, as far as possible, in intellectually accessible manner.

Just as dignity is portrayed as the dignity forthcoming from God, so we can argue that justice is forthcoming from God. Justice is the justice of God. Years ago B Wentsel ${ }^{9}$ discusses justice as God's justice. He argues that God's justice is constituted

9 B Wentsel, Hij voor ons, wij voor Hem. Over gerechtigheid, verzoening en gericht (Kampen: Kok, 1973), p 50-57. 
by a threefold virtue, namely justice as norming and guiding justice for all walks of life, justice as retributive justice, and justice as salvific justice.

All these dimensions of justice are based in the notion of the work of justification of the triune God. Justification entails that the triune God justifies and sanctifies sinners. God brings forgiveness and salvation, justification and sanctification. He transforms people into justified and sanctified ones who receive the vocation to seek justice in the world. Justification and sanctification are interdependent. We cannot talk about one without the other. Moltmann, ${ }^{10}$ in line with Luther and Calvin, describes justification as mortificatio sui, the dying to the self, and sanctification as the vivificatio Spiritu, life in the Spirit.

Justification paves the way for seeking justice in the world. Paul Lehman, ${ }^{11}$ who argued against the unhappy divorce between soteriology and ethics, views justification as what God does to set things right between humans and God. Justice, as the human quest to set things right amongst humans, is our faithful response to these actions of God.

When justice is understood as the setting right of what is not right in man's (sic.) relationship to man (sic), both private and public, then, the struggle for justice becomes the concrete expression, in behaviour, of man's (sic.) response to what God has done and is doing to set things right between man (sic.) and Himself. The faith by which man is justified becomes what Luther called a "busy, living, active thing" by which men learn in the struggle for justice what it means concretely to forgive and to be forgiven.

Luther's notion of living and effective faith parallels his understanding of justification as dynamic and effective, as the divine bringing forth and making of humans who are simultaneously sinful, on the one hand, and forgiven and just, on the other hand. These justified ones are continuously in search of personal and social justice through a process of self-judgement and repentance.

In a very helpful article Mark Seifrid discusses Melanchthon's and Luther's views on justification. $\mathrm{He}^{12}$ is concerned that Melanchthon interprets the important

10 J Moltmann, The Spirit of life: A universal affirmation (London: SCM, 1992), p.163 165.

11 PL Lehmann, Forgiveness, in J Macquarrie (ed.), The Dictionary of Christian Ethics, (Philadelphia: Westminster Press, 1967), p 131.

12 MA Seifrid, Luther, Melanchton and Paul on the question of imputation, in M Husbands and DJ Treier (eds.), Justification. What's at stake in the current debates? (Downer's Grove, Illinois: Inter Varsity Press/ Leicester, England: Apollos, 2004), p 148-150. 
notion of the imputation of Christ's righteousness in a reductionist way. He reckons that Melanchthon views justification - in an arid, juridical manner - as a means of quieting the conscience, and as a means of inward renewal. He runs the risk of viewing justification as a human possession, a human virtue. He does not view justification as a dynamic, sanative and continuous action of God as Luther does. For Luther, according to Seifrid, ${ }^{13}$ the imputation of righteousness is not merely the initial act by which God imparts salvation, but rather the continuous way in which God governs and purifies the life of the justified. It is a forensic and declaratory act, but it is also more. It is also an effective word of God, which paves the way for faith, daily repentance and self-judgment by which God "makes out of unhappy and proud gods, true human beings, that is, wretches and sinners." ${ }^{14}$ We might conclude that for Luther the divine declaration of justification is, therefore, also a continuous divine making into a just person of the sinner. ${ }^{15}$

Based on the idea that through justification God transforms humans beings into righteous and just persons, Stanley Hauerwas argues that the task of Christians is not only to formulate theories of justice, but in the first place and fundamentally to be just persons.

... For Christians, justice is first and foremost a claim about the kind of people we ought to be. You cannot have, contrary to liberal assumptions, a just social system, without people being just. The attempts to create such systems end in creating greater state power in the name of doing justice. Christians do not need such accounts of justice to know that the ill need care and the hungry need food. By learning to share their lives in the

13 MA Seifrid, Luther, Melanchthon and Paul, p 145.

14 Luther, as quoted by MA Seifrid, Luther, Melanchthon and Paul, p 151.

15 Seifrid's summary of Luther's dynamic understanding of justification, and of its implications for a life of personal and social justice, amidst sin and injustices, might be quoted at length:

Luther's dynamic conception of justification much more effectively conveys the way in which God's mercy is granted only in judgment. The justification of the sinner takes place only in and through the justification of God in the event of the cross and resurrection of Jesus Christ. "Justification" is no mere transaction to be applied to my account. God's "yes" is given only in and with his "no," a "no" and "yes" which are mine only in so far as faith echoes them in my heart. Both in the foolishness of pride and sin and in the despair of misery, suffering and failure, this Gospel of the justifying work of God in Christ both conquers and carries us sinners. 
church, Christians have learned that justice often demands no more than the most common acts of care. ${ }^{16}$

I understand Hauerwas' plea to be one that expresses the confidence that just people, people who do not forget the most basic calling to care, are well placed to participate in public quests for theories and systems, policies and practices of justice.

This discussion hopefully sheds some light on the relationship between God's justice and human justice, between justification and justice.

Where human justice is based in God's justice, there a richer understanding of justice is developed. We might identify two dimensions of the compassionate justice of article three of the Belhar Confession. It an be argued that the notion of compassionate justice implies that justice has a forensic or legal dimension and that it also has features like mercy, sacrifice, righteousness, reconciliation and restoration.

The Old Testament uses justice mainly in a twofold way, i.e. as forensic justice (mishpat), and as compassionate justice (tsedaqah). The New Testament dikaiosune carries both meanings. Bruce Birch ${ }^{17}$ describes mishpat as a term with a basic forensic character. It deals with judicial activities at every level. It is an ethical concept that deals with rights due to every individual in the community and with the upholding of those rights. Especially God's justice refers to the upholding of the rights of the vulnerable, and with the advocacy of their needs (Deut 10;18; Ps 10:18; Jer 5:28). Where the rights of the vulnerable is violated, God's justice can be translated as judgement, the activity of God to hold accountable those who deny, manipulate and exploit the rights of others.

Various theories of justice that developed in the post- Enlightenment era also strive to employ justice, amongst others through the notion of human rights, as a pathway towards homecoming for millions, i.e. enjoying the good of the land.

Tsedaqah, according to Birch, ${ }^{18}$ is also translated as righteousness. Here the focus is on right relationships. God's righteousness refers to his concrete acts to establish and preserve relationship. His law is a gift that aims at establishing terms under which

16 S Hauerwas, Should Christians talk so much about justice?, in: B\&R Reviews May/June 1986. p 6.

17 BC Birch, Let justice roll down. The Old Testament, ethics, and Christian life (Kentucky: John Knox Press, 1991), p 155-156.

18 BC Birch, Let justice roll down, p 153-154. 
relationship is preserved and maintained. ${ }^{19}$ Both the Old and New Testaments teach that sacrifice was required to achieve this rightness in relations.

Justice therefore stands in relationship to justification. Justification means that God declares us righteous because of the ultimate sacrifice of Christ. This imputed righteousness, i.e. righteousness that we possess because of our connectedness in faith to Christ, makes us people who practice justice. Those who are made righteous through a sacrifice also practice sacrificial justice. They know that relationships will not be right and prosperous and joyful without sacrifice.

A crucial dimension of justice is equality. Duncan Forrester ${ }^{20}$ argues that equality refers to equality in worth, dignity and value. Inequality is witnessed to in evils like racism, sexism, anti-Semitism etc.. He, however concedes that there is disagreement on how this equality of worth can be translated into policy and practice.

Oliver O'Donovan argues against an absolutistic equalization process. He is in favour of the notion of the equal worth of humans. He, however, reckons that this theological and metaphysical notion, which constitutes the foundations of society, should not be confused with the superstructure of human existence. Where revolutionary equalization causes this confusion, social structures are dissolved and degraded, and human life becomes unliveable. The metaphysical foundational principle of equal worth cannot be implemented in society without taking the complex differentiated nature of the structures of society into consideration. For him differentiation is the law of every social organism. Attributive justice, as justice of differentiation, is influenced by notions like affinity and bonds of loyalty, the promotion of talent, wise appointments to office, the provision of opportunities to those who could use them. "We depend on the justice of differentiation from the moment we take our first breath and are placed in the arms of our mother, rather than being handed to whoever may be next in the queue for a child." ${ }^{21} \mathrm{He}$ does, however, caution that this emphasis on justice of differentiation should not close our eyes for those kinds of difference, which are simply unjust.

O'Donovan ${ }^{22}$ suggests that we view persons as always equal in worth, but that we differentiate in roles and classes. Roles that we play are distinguished from each other and are not equal in an absolutistic sense. In the same way classes, communities

19 Tsedaqah can also be translated as vindication, deliverance, uprightness, right and even prosperity.

20 D Forrester, On human worth (London: SCM Press, 2001), p 30.

21 D Forrester, On human worth, p 42.

22 D Forrester, On human worth, p 43-44, 50-51. 
and collectives e.g. genders do have differences. Allocations to men's' health care and women's' heath care, to boys' education and to girls' education should not be done on a 50-50 basis, but in terms of what each requires in specific contexts and instances. He employs Paul's words in Galatians 3:28 to argue against the absolute or revolutionary equalization of classes.

Despite his plea for equality in the context of the justice of allocation and differentiation he identifies three thresholds where the metaphysical equality of worth should also be adhered to in practices and policies. There should be strict equality in cases where we fight against death for the saving of life. ${ }^{23}$ There should be strict equality with regard to the opportunity to live and to participate in society, since these constitute part of the heart of worth and dignity. ${ }^{24}$ The third threshold for strict equality is the equality before the law, where prosopolempsia, i.e. prejudice against the person, should not determine the process. ${ }^{25}$

In a very illuminating article Bram van de Beek $^{26}$ showed a few years ago how Calvin's perspectives on equality can enrich contemporary discussions on justice and equality in our pluralistic public domains. Van de Beek argues that equality cannot be understood as absolute equality. Equality should rather be understood in terms of the notion of aequitas that Calvin employs. Aequitas refers to the quest for equilibrium, for balance (Afrikaans: ewewig) in society. It implies that we need equity (from aequitas) measures to build a society of greater equilibrium, a society of balance, of moderation, where some do not have too much and others too little. A society of equilibrium is enhanced where we practice an ethos of self-denial, sacrifice, service and care, and where we do not only bear the burden of the other, but where we bear the other one as burden.

Justice is due to all people and creatures, because we have God-given, and therefore, inalienable, dignity, worth and value. Furthermore, justice is only present where freedom prevails.

In a helpful discussion of freedom Mark Mattes ${ }^{27}$ argues that all freedom quests betray our captivity to the tyranny that drives us to establish our worth. This is true of the freedom of the Stoics that teaches us to change our inner life and to accept that

23 D Forrester, On human worth, p 44.

24 D Forrester, On human worth, p 48-49.

25 D Forrester, On human worth, p 49-50.

26 A van de Beek, Beyond the unfounded optimism of equity, in E van der Borght (ed.), Affirming and living with differences (Zoetermeer: Meinema, 2003), p 147-160.

27 MC Mattes, The role of justification, $\mathrm{p} 108$. 
we cannot change the world; it is true of the freedom of the Epicureans that resides in pleasure in moderation; it is true of the freedom of the utilitarians which strive for the maximum autonomy provided that we do no harm to others; it is true of the freedom of Kant in which one needs to honour autonomy in oneself and in others and thus embody the kingdom of ends; it is true of the freedom of Hegel in which Spirit is working itself out in and through us; it is true of the Marxian freedom of the liberation of the proletariat; it is true of the Lockean freedom of self-ownership; it is true of the nihilistic freedom in which one exercises one's power as a god unto oneself and in a context where reality is described as competitive power plays apart from any summum bonum.

For Matte ${ }^{28}$ Christian freedom is freedom from the wrath of God that is manifested in our indifference to holy things, in our quest to control our destinies, and in pervasive meaninglessness. We are free for sheer enjoyment of God, the world and our lives. We are free from our ambitio divinitatis and our unwillingness to accept our humanity, especially our sinful dimensions. We are freed from the compulsion to establish our own worth and security. We are free for others, including nature, and therefore genuinely open to their needs and concerns.

O'Donovan argues that freedom is mainly understood in terms of our anxiety and fear about the freedoms that we might loose. "Freedom is the looking-glass in which we search our features anxiously for signs of 'unfreedom." ${ }^{29} \mathrm{He}$ argues that it is therefore difficult to construct positive programs around the idea of freedom. He makes suggestions for such positive definitions of freedom. Freedom is the power to act. ${ }^{30}$ Freedom is the realization of individual powers in social forms. ${ }^{31}$ Freedom is the individual's discovery and pursuit of his or her vocation from God. ${ }^{32}$ Freedom is lastly freedom from structures that exclude those who should be included. He draws last-mentioned perspective on freedom from liberation theology. ${ }^{33}$

28 MC Mattes, The role of justification, p 184.

29 O O'Donovan, The ways of judgment, $\mathrm{p} 68$.

30 O O'Donovan, The ways of judgment, $\mathrm{p} 67$.

31 O O'Donovan, The ways of judgment, p 68.

32 O O'Donovan, The ways of judgment, $\mathrm{p} 72$.

33 O O'Donovan, The ways of judgment, p 82-83. 


\section{THEOLOGY AND AN ACTIVIST CIVIL SOCIETY AND CITIZENSHIP FOR JUSTICE}

The second way in which the idea of a civilizing democracy is used in this presentation is to refer to the role of civil society in democracies. Civil society consists of all the institutions in society other than the political and governmental institutions - which some call the state - and business institutions - which some calls the market. Civil society, therefore, refers to institutions from the most intimate to the most global spheres of life. It includes institutions like marriage and families and circles of friends, as well as institutions of education, sport culture, art, voluntary organisations, trade unions (although some reckon that they belong to the market sphere), the media (although some reckon that they belong to a fourth public, namely the sphere of public discussion and public opinion-formation). Individual citizens and those individuals without formal citizenship status, and groups - all in their personal and voluntary capacities - also belong to the sphere of civil society. Churches and other religious organisations are, sociologically spoken, part of civil society. ${ }^{34}$

A plea is made that churches and other institutions of civil society, as well as individual believers, disciples, and other individuals in different walks of life, fulfil an activist role in society. By the notion of activism it is meant that civil society, in appropriate partnership with government and business, be actively involved in the building of a civilizing democracy of justice, dignity and freedom.

Theological insights can assist in defining this activism. Mark Mattes ${ }^{35}$ offers some parameters for the activist public engagement of theology and churches. We should always see our role as that of recipients and not as that of agents. The human is not homo agens semper. Rather we must ask with St Paul, what do you have that you have not received? (1 Cor 4:7). This means that we act as recipients of the kingdom of God, and not as agents of the kingdom. "... eschatology ought not to be a source of political self-potentiation for the sake of realizing the kingdom, but a reception of God's promise to provide. We pray that God's kingdom comes among us as well, for it is sure to come."36 We participate in God's work, but our participation is only

34 For a discussion of the notions of civil society and global civil society, see N Koopman, Global civil society, church unity and world unity, in: WF Storrar, PJ Casarella, PL, Metzger (eds.) A World for All? Global Civil Society in political theory and Trinitarian theology (Grand Rapids/Cambridge: WM. B. Eerdmans Publishing Co, 2011), p 108121.

35 MC Mattes, The role of justification, p 110-112.

36 MC Mattes, The role of justification, $\mathrm{p} 110$. 
poietic, not redemptive. We must acknowledge that nature is liberated, not yet perfected by grace. We must realize that social justice is not social perfection. ${ }^{37}$ As recipients, and not as agents, we see that the gospel views the social realm as an arena for securing human dignity, freedom of conscience, the right to education, important democratic ideals, expressions of God's providential grace in history. ${ }^{38}$

The doctrine of the threefold office of Christ might inform the activist role of churches, and to some extent, also the activist role of other institutions of civil society. An activist civil society might be a prophetic civil society, a priestly civil society and a servant civil society. A prophetic, priestly and royal-servant church might motivate and model to the rest of civil society such a threefold activism.

The prophetic activism might entail that we nurture the vision of a new society; that we courageously offer self-criticism and public criticism where this vision is betrayed; that we tell the stories of suffering and injustice, as well as the stories of small manifestations of justice; that we do technical analysis of burning public issues; that we actively participate in policymaking, policy-implementation and policy-monitoring and policy-amendment processes.

Priestly activism might entail that we seek reconciliation and healing in a world of division and various forms of alienation, i.e. physical, psychological, spiritual, economic, political, social and ecological alienation; that we practice an ethic of care and compassion and presence with wronged and suffering people.

A royal-servant presence might entail that we seek and model a discipleship, citizenship and leadership of servanthood, that we demonstrate that our Lord is Shepherd and Servant; that we demonstrate that ministers are servants, and that presidents are the ones who presides in servanthood; that we participate in moral formation processes in all spheres of life; that we nurture hope as realistic hope, responsive hope and resilient hope.

\section{CONCLUSION}

Public theology can serve churches, academy and broader society by advancing the building of a civilizing democracy of justice, justice that rests in dignity, justice that is expressed in sacrificial, compassionate, embracing justice, justice that coheres with equality and equity, justice that co-exists with freedom. In this process theology reveals the indispensable meaning-giving and motivating comprehensive frameworks and prerequisites for a flourishing democracy. Theology secondly offers

37 MC Mattes, The role of justification, p 110-112.

38 MC Mattes, The role of justification, p 184-185. 
richer descriptions of notions like dignity, justice, equality and freedom, which all enhance the implementation of these crucial features of a life of true civility. Theology thirdly assists to identify and mobilise the resources in churches, civil society and also in political and economic life to actively build this society of justice. 
